\title{
REVIEW
}

\section{History and perspectives of pituitary folliculo-stellate cell research}

Wilfried Allaerts and Hugo Vankelecom ${ }^{1}$

Biological Publishing, PO Box 104, NL-7440 AC Nijverdal, The Netherlands and ${ }^{1}$ Laboratory of Cell Pharmacology, University of Leuven (K. U. Leuven), Campus Gasthuisberg, Onderwÿs E Navorsing, Herestraat 49, B-3000 Leuven, Belgium

(Correspondence should be addressed to W Allaerts; Email: w.allaerts@planet.nl)

\begin{abstract}
Historically, the study of folliculo-stellate (FS) cells of the anterior pituitary dates back to the onset of electron microscopical observation of the pituitary gland. The morphological and electrophysiological characteristics, topographical distribution and contribution to intercellular junctions of these FS cells have been instrumental to the understanding of their putative function. Moreover, many studies have documented the role of FS cells as a source of newly discovered peptides, growth factors and cytokines. Quantitative immunohistochemical observation of FS cells in situ and functional in vitro studies, using either cultured FS cells or cells from an immortalized FS cell line, forwarded the notion of immunophenotypical and functional heterogeneity of the FS cell group. Double immunolabeling with a classical FS cell marker (S-100 protein) and with major histocompatibility complex class II markers characteristic for dendritic cells (DC) have shown a considerable overlap of FS cells with DC. The latter cells are immunocompetent cells belonging to the mononuclear phagocyte system. In this review, the FS cell heterogeneity is discussed with respect to the question of their embryological origin and developmental fate and with respect to the physiological relevance of functionally heterogeneous subpopulations. Recent findings of a myeloid origin of part of the interstitial cells of the anterior pituitary are confronted by other developmental paradigms of pituitary cell differentiation. The possibility that FS cells represent an adult stem cell population of the pituitary is critically examined. Also the physiological role of FS cells in the interferon- $\gamma$ - and nitric oxide-mediated effects on pituitary hormone secretion is discussed. New approaches for the study of this enigmatic cell group using immortalized cell lines and new markers for an hitherto unrecognized pituitary cell population, the so-called 'side population', are evaluated.
\end{abstract}

European Journal of Endocrinology 153 1-12

\section{Introduction}

The history of the study of folliculo-stellate (FS) cells in the anterior pituitary dates back more than half a century. Already in the early days of electron microscopy, the anterior pituitary was considered an interesting organ for electron microscopic studies $(1,2)$, and the peculiar nature of FS cells was soon discovered. The name 'folliculo-stellate' cells, coined by Vila-Porcile (3), was given to cover the diverse aspects of their morphology and putative function. On the one hand, FS cells were described as non-endocrine stellate-shaped cells and were considered to act as supporting cells for the endocrine cells. On the other hand, FS cells were lining follicle-like cavities and therefore were also named 'follicular cells'. Many authors continued to call them follicular cells, these being identical to FS cells (3). Moreover, they were found to be involved in trophic and catabolic processes and in macromolecular transport $(4,5)$. In addition, FS cells shared properties with dendritic cells (DC) and also with macrophages, which related them to the mononuclear phagocyte system $(6-8)$.

FS cells were found to be a source of newly discovered growth factors and peptides such as basic fibroblast growth factor (bFGF) (9), vascular endothelial growth factor (VEGF) $(10,11)$ and follistatin (11), as well as of cytokines such as leukemia inhibitory factor (LIF) (12), interleukin (IL)-6 (13) and macrophage migration inhibitory factor (MIF) (14). FS cells were also shown to respond to $\beta$-adrenergic stimuli and displayed enhanced cAMP-accumulation upon $\beta$-adrenergic stimulation (15). Some groups have studied in more detail the involvement of FS cells in dipeptide uptake mechanisms (16), or their role in a local pituitary cytokine network $(13,14,17)$. Finally, their role in the production of the radical nitric oxide (NO) and in NO signaling (18-20) brought them into the limelight 
again when the role of $\mathrm{NO}$ in the regulation of pituitary hormone secretion was discovered $(18,21)$. The electrophysiological properties of presumed FS cells have been studied in detail in the amphibian Xenopus laevis (22). Older studies have especially focussed on the transport epithelial characteristics of FS cells (23) and the contribution of FS cells to the regulation of the pituitary interstitial environment (23), and to paracrine communication with pituitary hormone-secreting cells $(24,25)$.

Already in 1975, gap junctions were described between follicular cells of the rat anterior pituitary by Orci and co-workers (26). It was also suggested that homologous pituitary cells could presumably form an electrically coupled functional syncytium (27). However, more than 20 years later Fauquier et al. (28) provided evidence for electrical coupling of FS cells via calcium waves, propagating through gap junctions within the FS cell network. This electrically coupled FS cell network was suggested to provide a mechanism for long-distance communication in the anterior pituitary in response to physiological stimuli (28). The finding of thyrotropin (TSH) receptors expressed in a subpopulation of FS cells in situ and in cell lines also opened a new perspective on ultra-short feedback loop regulation by FS cells of TSH secretion $(29,30)$.

In the Japanese school of $\mathrm{F}$ Yoshimura and coworkers, the idea that FS cells form a renewal cell system for endocrine cells, similar to the adult stem cell system of the brain $(31,32)$, persisted from the late 60s (33) until the present day $(34,35)$. Both the establishment of an immortalized FS cell-derived cell line (36), as well as the growing interest in transdifferentiation processes in the pituitary $(35,37-39)$, have shed new light on these 'old' concepts. Although fundamental insight has been gathered on cell lineage relationships and development during embryogenesis of the pituitary, little is known about cell development and homeostatic cell turnover in the adult gland. Formation of new hormone-producing cells involves mitosis of existing differentiated cells, but also, and apparently to a higher extent, maturation of undifferentiated cells $(40,41)$. It has repeatedly been suggested that stem/progenitor cells are implied in this process of pituitary cell turnover (40-42). At present, stem/progenitor cells are being found in a growing number of adult tissues, but have not been identified yet in the pituitary. FS cells have more than once been suggested to play a role as stem cells $(34,37)$. Convincing evidence for a phenotypical change of FS cells into other pituitary cell types, however, is still to be provided. A contemporary concept related to stem cells is that of 'transdifferentiation' of cells, which can even occur across germ cell layers, such as neural stem cells giving rise to hematopoietic cells (32). As mentioned, transdifferentiation processes such as the conversion between acidophilic cell types (lactotropes and somatotropes) also take place in the pituitary $(38,39)$.
Multiple basic questions, however, remain, and these may be redefined and re-investigated by implementing new technologies. The question, formulated by Inoue as 'Are FS-cells in the anterior pituitary gland supportive cells or organ-specific stem cells?' has not been unequivocally answered at present, and possibly the answer is dual. Questions like these may be formulated in terms of a few basic questions: (a) what is the relation between structure and function of FS cells? (see 'Morphology and function of FS cells' below) and (b) what is the embryological origin and fate of these cells? (see 'Embryological origin of FS cells and functional implications of FS cell heterogeneity' below). From the observation of multiple morphologies and functions, the following question directly results: (c) is the FS cell group heterogeneous and does the morphological heterogeneity also reflect a functional heterogeneity, or does it mark different developmental stages? (see 'Embryological origin of FS cells and functional implications of FS cell heterogeneity' and 'New approaches for old questions' below). Moreover, the latter question (c) implies that caution is needed because of the following: (d) what is the in vivo relevance of some of the in vitro findings? and (e) what is the influence of culture conditions upon FS cell physiology? (see 'New perspectives in FS cell physiology' below).

\section{Morphology and function of FS cells}

\section{Morphology of FS cells and compartmentalization of the anterior pituitary}

The concept of a stellate-shaped, supporting cell type in the anterior pituitary originates from the early electron microscopic studies of pituitary cells (1). Originally, these stellate-shaped cells were believed to be corticotropes (2). The name folliculo-stellate cell (FS cell) was coined by Vila-Porcile (3), to unite the concepts of a stellate cell type with long extensions spreading between the epithelial cell chords $(1,43)$, and of an epithelial follicular cell type (44) lining an anastomosing network of follicles and lacunae in the adenohypophysis.

In our first review (4), we discussed some conflicting viewpoints in the literature on the compartmentalization of the pituitary interstitial environment. This compartimentalization was due to the formation in situ (26, $45)$ and in vitro $(23,46)$ of tight junctional barriers between FS cells. The apparent discrepancy of a 'tight' barrier (corresponding to completely ramified tight junctions) $(23,46)$ and our observations of good permeability of cell aggregates in vitro (25) could be traced to the type of cell culture used. Observations in situ revealed a 'leaky' barrier corresponding to incompletely ramifying tight junctions $(26,45)$. In vitro studies using static monolayer cultures, with pituitary cells (46) or enriched FS cells (23) plated at high density, resulted in the formation of confluent monolayers and also 'tight' diffusion barriers and dome formation (23). In our studies, however, we 
used three-dimensional (3D) re-aggregated cell cultures, obtained by gyratory shaking of isolated pituitary cells in suspension, yielding a more histotypic cell culture system of the rat anterior pituitary $(24,25)$. Permeability studies of the interstitial environment in FS cell-enriched cell aggregates (47) confirmed the leakiness of intercellular junctions in vitro, similar to intercellular junctions in the rat anterior pituitary in situ $(3,26,45)$.

\section{FS cells in paracrine communication in the anterior pituitary}

In the 30 years following their description, a variety of roles in pituitary support, metabolism and transport have been ascribed to FS cells (for review see 4). Insight into FS cell function had a new launch when, about two decades ago, Denef and co-workers identified FS cells as cells endowed with paracrine regulatory activities. During the search for a paracrine factor involved in lactotrope-gonadotrope communication $(48,49)$, a factor was unexpectedly detected that caused the attenuation of secretion responses to either stimulatory (24) or inhibitory hormones (25) (see Table 1). This attenuating effect was more pronounced in cell aggregates obtained from low-density gradient fractions, in which FS cells (i.e. cells immunopositive to S-100 protein) $(50,51)$ were the most prominent cell type $(24,52)$, and correlated with the proportion of FS cells present in recombined gradient fractions. It was suggested that this inhibitory effect represents a mechanism of homeostasis with important regulatory function in the anterior pituitary in vivo (4). Evidence was provided that this inhibitory activity was mediated by a paracrine factor secreted by FS cells (24). Almost simultaneously, a number of candidate paracrine substances were discovered and reported to be secreted by FS cells (bFGF (9), VEGF (10, 11), follistatin (11) and IL-6 (13, 53)) (for review see 4). However, several of the candidate factors identified in FS cells (e.g. S-100, bFGF and IL-6) were found to exert a stimulatory effect on the secretion of various pituitary hormones in cultured pituitary cells or cell lines (see Table 1). On the other hand, IL-6 was found to have a small but significant inhibitory effect on corticotropin-releasing factor (CRF)-stimulated adrenocorticotropin (ACTH) secretion (in monolayer cultures) (H Vankelecom, unpublished observations).

The next methodological question raised was whether, in the absence of normal physiological regulation and feedback mechanisms, an inhibitory effect of FS cells on hormone secretion in culture could be provoked by particular in vitro conditions. IFN- $\gamma$ was found to inhibit the stimulated secretion of ACTH, PRL and GH in rat anterior pituitary monolayer and aggregate cell cultures (57). This effect was mediated through FS cells present in recombined cell cultures (17). This finding was instrumental in the discovery of $\mathrm{NO}$ as one of the mediators of the FS cell inhibitory action. Similar to its activity in macrophages, IFN- $\gamma$ stimulated the expression of inducible NO synthase (iNOS) in FS cells, at least part of them, and the NO produced was shown to mediate the inhibitory effect of IFN- $\gamma(19,20)$. IL-6, on the other hand, was not involved since antibodies to IL-6 were unable to block the effect of IFN- $\gamma$ on stimulated hormone secretion (H Vankelecom, unpublished observations). Expression of the constitutive isoform of NO synthase (cNOS) was previously demonstrated in gonadotrophs and FS cells of rat anterior pituitaries (18). Also in the amphibian Xenopus laevis, FS cells as well as endocrine

Table 1 Effects of FS cells or FS cell-derived factors on anterior pituitary (AP) hormone secretion: an overview.

\begin{tabular}{|c|c|c|c|}
\hline $\begin{array}{l}\text { System of FS cells or } \\
\text { FS cell-derived factors }\end{array}$ & Type of culture & Effect on AP hormone secretion & Reference \\
\hline \multirow[t]{4}{*}{ FS cell-enriched population } & \multirow[t]{4}{*}{ Coculture in 3D cell aggregates } & $\downarrow$ GRF-stimulated GH & 24 \\
\hline & & $\downarrow$ Epinephrine-stimulated GH & 24 \\
\hline & & $\downarrow$ Angiotensin II-stimulated PRL & 24 \\
\hline & & $\downarrow$ LHRH-stimulated LH & 24 \\
\hline $\begin{array}{l}\text { Conditioned medium from FS } \\
\text { cell-enriched population }\end{array}$ & 3D cell aggregates of lactotropes & $\downarrow$ Angiotensin II-stimulated PRL & 24 \\
\hline \multirow{3}{*}{ FS cell-enriched population } & \multirow[t]{3}{*}{ Coculture in 3D cell aggregates } & $\uparrow$ Dopamine-inhibited PRL & 25 \\
\hline & & $\uparrow$ SRIF-inhibited GH & 25 \\
\hline & & $\downarrow$ LHRH-priming of $\mathrm{LH}$ in subsequent pulses & 52 \\
\hline TtT/GF cells & Mixed monolayer cultures with $\mathrm{GH} 3$ cells & $\begin{array}{ll}\uparrow \uparrow & \text { Basal PRL } \\
\uparrow \uparrow & T R H \text {-induced PRL }\end{array}$ & 109 \\
\hline S-100 & Pituitary cell line & $\uparrow \uparrow \mathrm{PRL}$ & 54 \\
\hline bFGF & Long-term pituitary cell culture & $\uparrow \uparrow \mathrm{PRL}, \mathrm{TSH}$ & 55 \\
\hline IL-6 & Perifused AP cells & $\uparrow \uparrow \mathrm{PRL}, \mathrm{GH}, \mathrm{LH}$ & 56 \\
\hline IL-6 & Monolayer cultures of AP cells & $\downarrow$ CRF-stimulated ACTH & 57 \\
\hline IFN- $\gamma$ activated FS cells & Monolayer cultures of AP cells & $\downarrow$ Stimulated $\mathrm{ACTH}, \mathrm{PRL}, \mathrm{GH}$ and basal PRL & 17,57 \\
\hline MIF & TtT/GF cells & $\uparrow$ Dex-inhibited endotoxin-induced IL 6 & 14 \\
\hline
\end{tabular}

$\left(^{*}\right) \downarrow$ means 'inhibits'; $\uparrow$ means 'attenuates' inhibition; $\uparrow \uparrow$ means 'stimulates'.

IFN- $\gamma$, interferon $\gamma$; GRF, growth hormone releasing factor; GH, growth hormone; PRL, prolactin; LH, luteinizing hormone; LHRH, LH-releasing hormone; MIF, macrophage migration inhibitory factor; SRIF, somatostatin; TRH, thyrotropin-releasing hormone; ACTH, adrenocorticotrophic hormone; dex, dexamethasone. 
cells of the pituitary pars intermedia were capable of NO production in vitro (58). However, because of its very short half-life, NO is in itself unlikely to represent the inhibitory factor present in medium conditioned by FS cell-enriched cell populations. The search for a FS cellderived factor that causes the attenuation of pituitary hormone secretion responses $(18-20,24,25,57)$ thus raised new questions on the physiological significance of NO in the pituitary (58).

It was recently shown that annexin-1 (ANXA1) in the pituitary is principally expressed in FS cells (59). Annexins are a group of proteins that share the property of interacting with membranes in a $\mathrm{Ca}^{2+}$-dependent manner. Tierney et al. (59) demonstrated that glucocorticoids cause the exportation of ANXA1 from FS cells and that corticotrophs express ANXA1-binding sites. These observations led to the conclusion that ANXA1 acts as a paracrine or juxtacrine mediator of the early inhibitory effects of glucocorticoids on ACTH release (59).

The general inhibitory effect of FS cells on pituitary hormone secretion initially raised the question as to whether a reduced permeability or stereological impediment of secretagogues to reach their target cells might be at stake (47). The concern about steric effects was a genuine one in view of the tight compartmentalization of the interstitial environment suggested by some in vitro studies $(23,46)$ (see 'Morphology of FS cells and compartmentalization of the anterior pituitary' above). Diffusion barriers, however, were not present, as shown by real-time permeability studies in pituitary cell aggregates together with deconvolution techniques for the calculation of hormone secretion patterns (47) and, most particularly, by the observation of long-term effects of FS cells in a biphasic hormone secretion model (52). The latter secretion model was the biphasic LH secretion response to repeated pulses of gonadotropin-releasing hormone $(\mathrm{GnRH})(60,61)$. FS cells were found to diminish the self-potentiating effect of GnRH in gonadotropes, by attenuating the differences in secretion rate between early and late LH responses to GnRH in the same cell aggregates (52). The mechanisms involved in the latter aspect of homeostatic control, however, are still unsolved. Masumoto et al. (62) suggested a role for IL- 6 and intracellular free calcium $\left(\left[\mathrm{Ca}^{2+}\right]_{\mathrm{i}}\right)$ in the paracrine regulation of GnRH-induced LH secretion from purified gonadotropes. FS cells have been shown to be producers of IL-6 in the anterior pituitary $(13,53)$, and $\left[\mathrm{Ca}^{2+}\right]_{\mathrm{i}}$ waves were demonstrated in FS cell networks that are intimately associated with endocrine cells (28). The hypothesis, which remains to be tested, is that electrical coupling of FS cells (28), in separate or in mixed electrically coupled systems with gonadotropes, may cause the long-term effects on GnRHinduced LH secretion (52). Alternatively, NO released from gonadotropes or FS cells $(18,19)$, or from as yet unidentified cells (19), may form a distinct pathway of autocrine or paracrine regulation respectively of gonadotropin secretion (see also legend to Fig. 2).
To conclude, the permeability studies, as well as recent electrophysiological studies, have corroborated the role of FS cells in the local homeostatic control of pituitary hormone secretion. Clearly, further research into these processes is needed to bring together the different pieces of the puzzle.

\section{Embryological origin of FS cells and functional implications of FS cell heterogeneity}

\section{Immunophenotype and FS cell heterogeneity}

The issue of FS cell heterogeneity was launched by the observation of different markers in subpopulations of FS cells: a proportion of FS cells was found to co-express S-100 and glial fibrillary acidic protein (GFAP), a proportion to contain both S-100 and keratin (63), and some FS cells to co-express S-100 or GFAP and vimentin (64) (Fig. 1, right column). This heterogeneous character was reinforced by the detection of immunohistochemical, morphological and ultrastructural resemblance between DC and FS cells (6). The relationship between DC and other cell types of the mononuclear phagocyte system such as monocytes and macrophages and their occurrence in the pituitary has been reviewed in (7). Co-localization studies of markers for DC, such as the major histocompatibility complex (MHC)-class II antigen, and the marker for FS cells (S-100) yielded some important findings: (a) using double immunolabeling at the electron- and lightmicroscopic level, cells expressing both S-100 and MHC-class II antigen were found, but co-expression occurred only in $10-20 \%$ of the S- $100^{+}$cells (6) (a proportion remarkably similar to the one expressing iNOS after activation by IFN- $\gamma$ (20)) and (b) the expression of both S-100 $(65,66)$ and MHC-class II antigen did not occur before the postnatal age of 2 weeks in rats (67) or in the chick at hatching (68).

FS cells have also been indicated as the source of several cytokines that are normally produced by peripheral immune cells (see 'New perspecives in FS cell physiology' below). Very recently, Tierney et al. (14) found immunoreactivity to the proinflammatory cytokine MIF in part of the S-100 ${ }^{+}$FS cells and in some endocrine cell types.

Clearly the anterior pituitary FS cell population does not consist of a uniform cell type, but embraces subpopulations of different immunophenotype, some of which may not even be identified yet. Whether these subsets represent different cell types, or different stages of development/activation, remains an intriguing question.

\section{Immunophenotype and embryological origin}

The immunohistochemical resemblance between DC and FS cells, at least part of them, places the question of the embryological origin of FS cells in the forefront 

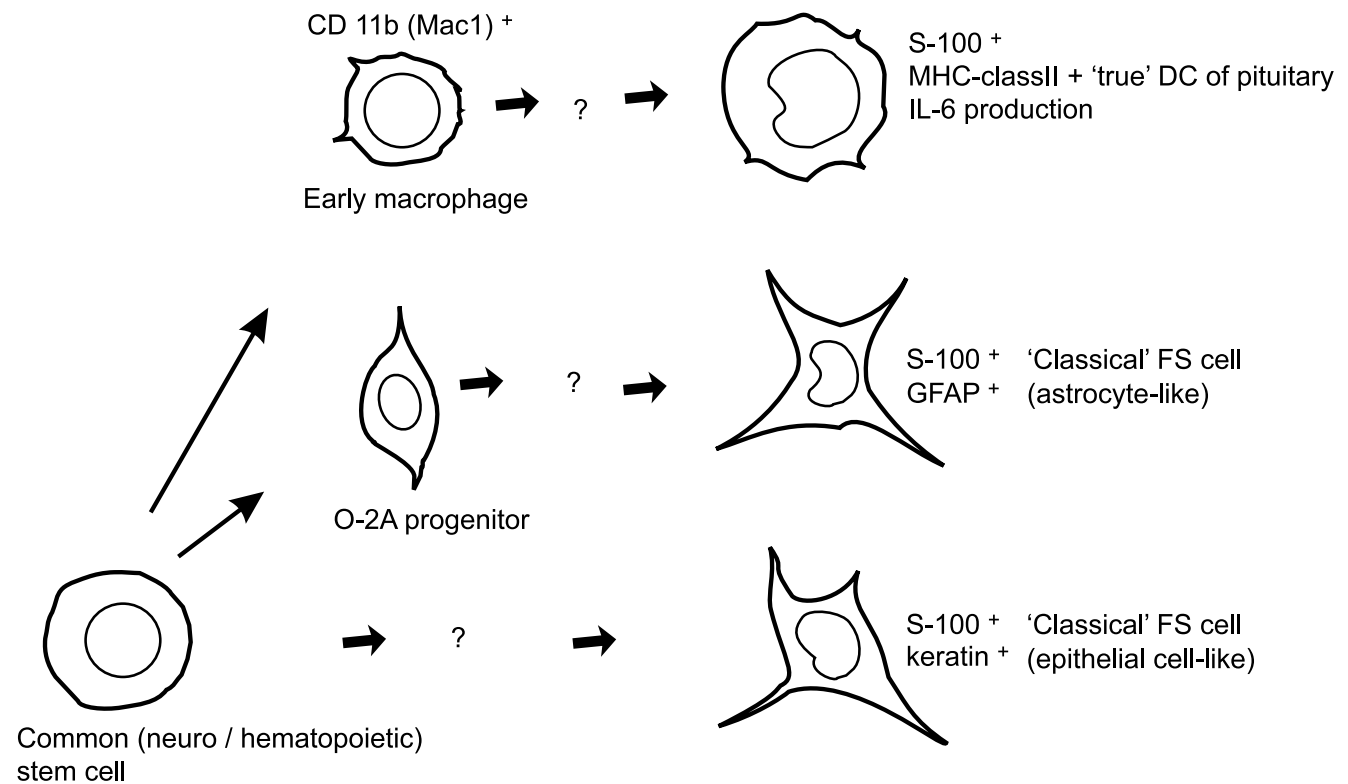

Figure 1 Hypothetical scheme representing the three (main) developmental pathways that may give rise to the adult population of DC and FS cells in the adenohypophysis. In the upper pathway, the pituitary DC that are represented are derived from the monocytemacrophage lineage, and those in the embryonic stage are probably derived from Mac- $1^{+}$early macrophages. In the middle pathway, 'classical' FS cells are depicted which share immunophenotypical characteristics (like GFAP expression) with astrocytes in the central nervous system. These astrocytes are known to be derived from bipolar O-2A progenitor cells (107), but a possible involvement of these O-2A progenitors in the development of FS cells is hypothetical. In the bottom pathway, a third group of FS cells (also called 'classical') is depicted, the members of which are presumably derived from an epithelial cell type in Rathke's pouch, based on the expression of keratin and of pitutary homeobox protein (Ptx-1) (108), a transcription factor present in all hormone-secreting cell types. All three cell types are immunopositive to S-100, at least at the adult age. In the lower left corner, a hitherto undefined common neuro/hematopoietic stem cell is shown, this may represent the common ancestor cell of all DC and FS cell lineages.

again. A variety of origins have been proposed (4) since the discovery of S-100 immunoreactivity in FS cells $(50,51)$. In view of the fact that DC in lymphoid and non-lymphoid tissues also express S-100 immunoreactivity (69), the possibility of a myeloid origin of $\mathrm{S}-100^{+}$cells in the pituitary has been considered in some studies. To examine the presumed bone marrow (BM) origin of (a subpopulation of) FS cells (7), $\gamma$-irradiated mice were transplanted with BM of transgenic mice whose DC can be specifically killed using ganciclovir (GCV) and 'the thymidine kinase obliteration' system (70). S-100- as well as MHC-class II-expressing cells in the pituitary from mice transplanted with transgenic BM were relatively unaffected by GCV-induced ablation of DC (67). However, some of the interstitial pituitary cell populations did show sensitivity to GCV and hence pointed to a BM origin (67): pituitaries were depleted from cells expressing the early macrophage differentiation antigen mac-1 (CD11b) (71, 72) or the macrophage antigen MOMA1 (73). In contrast, administration of granulocyte-macrophage colony-stimulating factor, known to stimulate transition from monocytes into DC (74), to the BM-recipient mice in the absence of GCV treatment increased the number of mac- $^{+}$and MOMA1 ${ }^{+}$cells in the mouse pituitaries compared with control mice (67). In embryonic chicken pituitaries, another early macrophage marker
(CVI-ChNl-68.1) (75) was found with a similar tissue distribution and developmental pattern as observed for mac- 1 in the mouse (68). CVI-ChNl-68.1 ${ }^{+}$macrophages were infiltrating the anterior pituitary of the chick well before full maturation of the pituitary, and also before mature DC (MHC-class $\mathrm{II}^{+}$) and FS cells $\left(\mathrm{S}-100^{+}\right)$were observed in the pituitary (68) (Fig. 1, middle column). To conclude, although no final proof for a BM origin of DC or FS cells in the anterior pituitary of adult rats and mice was found, the search for a possible hematopoietic precursor led to the discovery of BM-derived, early macrophage differentiation antigen-expressing cells, both in the adult mouse (67) and in the embryonic chicken adenohypophysis (68).

In order to understand FS cell origin and also lineage relationships both from a developmental and evolutionary viewpoint, a characteristic marker would be useful that allows for comparison in a variety of model species in different vertebrate taxa (e.g. mammals, birds, amphibians, teleosts). S-100 was found to be a marker for FS cells in the rat $(50,51)$ and in various mammalian species as well as in birds (68). However, in the pituitary of the amphibian Xenopus laevis, S-100-like immunoreactivity was present in pituicytes and fibers in the pars nervosa, and also in endocrine cells of the pars distalis, but not in the FS cells of the pars intermedia (W Allaerts, unpublished observations). This finding questions the 
usefulness of S-100 as a universal marker for FS cells, despite its expression in several species, from an early time-point in evolution (e.g. in Schwann cells of the bicolor damselfish Pomacentrus partitus, a tropical marine teleost) (76), and despite its presumed sequence conservation (66). Furthermore, since species barrier problems with non-conserved epitopes in peptide markers cannot be excluded, other markers should also be considered.

FS cells may be characterized using lectin histochemistry, which may be a useful tool especially in nonmammalian vertebrates. Specific lectin markers for FS cells are the Griffonia simplicifolia lectin (GSA) II as shown in the rat (77) or the lectin from the tomato (Lycopersicon esculentum) (78). Alternatively, FS cells may be visualized by their capacity for $\beta$-Ala-Lys-N $\epsilon-$ AMCA uptake (16), which feature is also present in FS cells of Xenopus laevis (58).

Finally, recent approaches based on transgene technology (79) may yield promising tools to study FS cell lineage relationships (see "New approaches for old questions' below).

\section{Functional heterogeneity}

The heterogeneity of FS cells also has implications for their functional characterization. Separation of FS cell subtypes, by using distinct cell separation techniques or combinations thereof, particularly affects their accessory function (which is absent in the purified S- $100^{+}$MHC-class $\mathrm{II}^{-}$subpopulation. Moreover, it also largely reduces the IL- 6 production in S-100 MHC-class $\mathrm{II}^{+}$and S- $100^{+}$MHC-class II populations (80). Thus, paracrine communication between FS cell subpopulations (80) might be an important condition for achieving the high IL-6 production rates as observed in pituitary cells in vitro $(13,81)$.

Cell culture conditions may also have a major impact on the (heterogeneous) phenotype of the FS cell population adopted in culture. Cell differentiation studies have revealed an important role of culture conditions in establishing a certain immunophenotype of cells of the monocyte-macrophage lineage including DC (7). Also the morphology of FS cells in culture appears to be dependent on culture conditions, like seeding condition, coating characteristics of the substratum (58) and method of culturing, either stationary (as monolayers) or on a gyratory shaker in free floating conditions (as aggregates) (4) (see 'Morphology of FS cells and compartmentalization of the anterior pituitary' above).

Finally, functional studies on FS cell subpopulations may be facilitated by the recent availability of immortalized cell lines. Inoue et al. (36) established a folliculostellate-like cell line (TtT/GF) from a murine thyrotropic pituitary tumor. The cell line showed several characteristics of FS cells in situ, and displayed stable expression of GFAP and S-100 after repeated passages (36). Considering that S-100 and GFAP are co-expressed in only 30\% of FS cells (63), Inoue et al. (82) have most probably stabilized an immunophenotype that corresponds to a subset of the FS cells in the anterior pituitary. These immunocytochemical data and also the lack of neuronal NOS expression in TtT/GF cells confirm the functional and ontogenetical heterogeneity of the FS cell group (82). Functional studies on these TtT/GF cells revealed that the cells secreted a tissue inhibitor of metalloproteinase (TIMP-II) (83), and that they responded to the novel hypophysiotropic peptide, pituitary adenylate cyclase-activating peptide (PACAP), which appeared to enhance the release of IL-6 in TtT/GF (84) as well as in normal pituitary cells (85). It remains to be shown whether PACAP is involved in the paracrine communication of FS cell subpopulations (80), and whether PACAP expression is required for achieving the high IL-6 production rates as observed in pituitary cells in vitro $(13,81)$.

\section{New perspectives in FS cell physiology}

In 1996 it was found that presumed FS cells in the pituitary pars intermedia of Хепориs laevis displayed quite distinct electrophysiological characteristics as compared with endocrine cells of the gland (22). For instance, FS cells did not fire action potentials and did not receive spontaneous inputs (22). Also, the membrane resistance was much less than that of melanotropes of the pars intermedia. Despite the fact that FS cells were suggested to be non-excitable cells (22), and that for a long time they were considered as nonhormone producing cells in view of the absence of hormone secretion granules (3-5), they do respond to a number of secretagogues (see e.g. 15).

During recent years, an increasing number of growth factors and cytokines have been detected in the anterior pituitary. A still growing list includes S-100 (54), bFGF (9), VEGF and follistatin $(10,11)$, IL-6 (13, 53, 81), LIF (12), MIF (14) and IL-10 (86). FS cells were indicated as the most plausible source of (most of) the latter growth factors and cytokines, although, for instance in human pituitary adenomas, evidence was provided that S- $100^{+}$FS cells were not the major source of Il-6 (87). Several studies, however, have documented the phenotypical changes in the FS cell population in pathophysiological conditions such as in pituitary adenomas $(88,89)$. In addition, the altered cytokine production profiles in pituitary adenomas $(90,91)$ also cautions against conclusions based on findings obtained from neoplasms only. Another reason for caution relates to the culture conditions as illustrated for LIF production by human astrocytes, only detected in astrocytes after being subcultured and not in primary cultures of astrocytes in close contact with neurons (92). In human leptomeningeal fibroblasts, LIF gene expression and protein synthesis have also been found (92). Since fibroblasts may grow 
in many cell culture systems, one has to be careful in pinpointing the cytokine production source in cultures.

It is noteworthy that production of growth factors and cytokines seems to be inducible in FS cells (e.g. see 85), and FS cells at least seem to be 'excitable' in this respect. Moreover, the detection in vitro of numerous receptors in FS cells (15) or TtT/GF cells (93-95), as well as of $\left[\mathrm{Ca}^{2+}\right]_{\mathrm{i}}$ rises in response to certain stimuli (94), further point to the 'excitable' nature of these cells. On the other hand, the occurrence of TSH receptors in a subpopulation of FS cells also expressing MHC-class II receptors (29) points to a possible role of these receptors in the immune accessory function of this FS cell subpopulation. Functional TSH receptors are also found in TtT/GF cells; these, however, are not coupled to cAMP or inositol 1,4,5-triphosphate pathways, but probably signal through the Janus kinase/signal transducer and activator of transcription 5a pathway (30). Interestingly, Horvath \& Kovacs (37) observed a marked activation and increase in number and size of FS cells in areas of ongoing immune destruction in lymphocytic hypophysitis, supporting their immune role.

An important question that remains largely unsolved is how the FS cells contribute to a locally active pituitary cytokine network, and how this system is altered in pathological conditions. The latter question is also related to the possible role of $\mathrm{NO}$ as a mediator of this cytokine network (Fig. 2). Indirect evidence was found for NOS activity in rat somatotropes in vitro, resulting in the inhibition of GH-releasing hormoneinduced GH secretion (21). Based on immunohistochemical data, Ceccatelli et al. (18) suggested that endogenous NO released from FS cells (constitutively produced by cNOS) would preferentially act on somatotropes or possibly in an autocrine manner when produced by gonadotropes. Gonadectomy resulted in the upregulation of cNOS mRNA and protein in the pituitary. Ceccatelli et al. (18) further suggested that NO participates in the pulsatile secretion patterns of $\mathrm{LH}$ and GH (18). Apart from being a player in the intrapituitary cytokine network, NO production - in particular by FS cells - may also represent a point of contact between the endocrine and the immune system in view of its activation by IFN- $\gamma$ (19).

The relationship between cytokine transduction pathways and NO production, respectively NO spillover into the cerebrospinal fluid, has been demonstrated in the brain (86). In the anterior pituitary, FS cells are an important link in this signaling pathway $(19,20)$, and moreover they may function as a model system to study the role of NO and cytokines in the communication between neurons and glial cells (see e.g. 92).

Relatively few studies have addressed the issue of which transduction pathways are activated in pituitary cells that are involved in the above-mentioned pituitary cytokine network. As mentioned above, FS cells were shown to be involved in the IFN- $\gamma$-induced inhibition of pituitary hormone secretion (17), but little is known

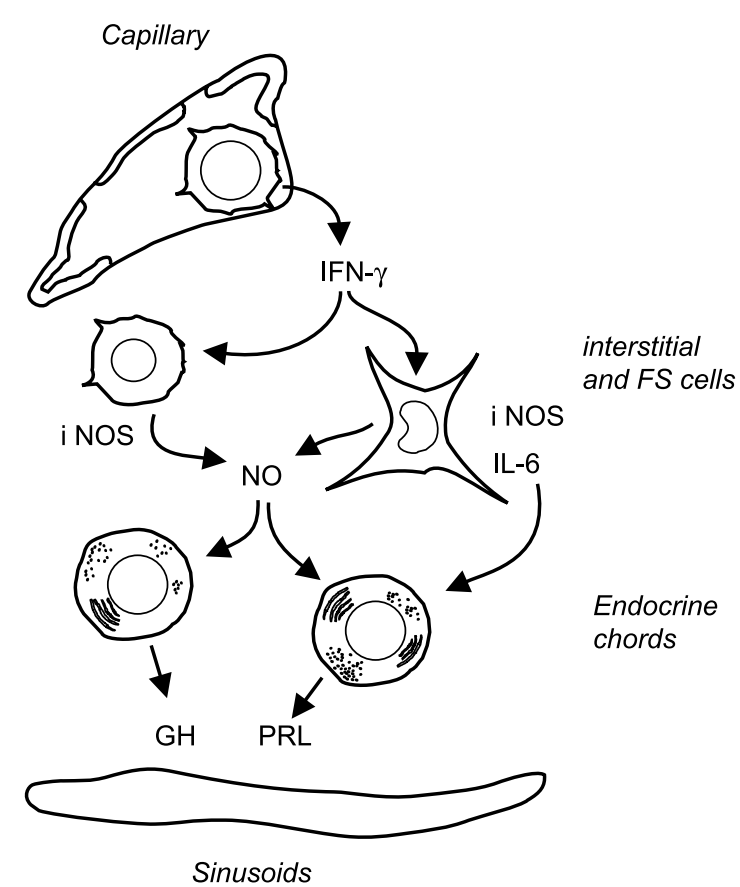

Figure 2 Schematic representation of the role of NO as a hypothetical link between pro-inflammatory cytokines (like IFN- $\gamma$ ) and pituitary hormone secretion. IFN- $\gamma$ released by infiltrating hematopoietic cells triggers iNOS expression in FS cells and possible other interstitial cells (unidentified, chromophobe cells), and stimulates production of NO. Alternatively, NO produced by gonadotropes regulates $\mathrm{LH}$ secretion in an autocrine manner (not shown). NO in turn stimulates or inhibits the secretion of several pituitary hormones. The cascade of molecular events downstream of the activation of NO - the soluble guanylate cyclase pathway - is rather complex and therefore was not included.

about the IFN- $\gamma$-activated signaling pathway in FS cells at the transcription or protein synthesis level. Various cytokines use different signal transduction pathways, thus increasing the complexity of the FS cell signal transduction machinery. However, it is also known that many cytokines, e.g. IL-6, IL-11, oncostatin M and LIF (96, 97), exert pleiotropic biological effects with significant overlap. The reason for this redundancy has been ascribed to the nature of the receptor complexes (cytokine class I receptor type), which share the gp130 molecule as a common receptor subunit $(97,98)$. Although, in the TtT/GF cell line, specific IL-11 (93), ciliary neurotropic factor (93) and tumor necrosis factor receptors (94) have been detected, so far no cytokine receptors have been demonstrated in FS cells in situ. IFN- $\gamma$, on the other hand, uses the distinct class II receptor signaling pathway (98). The heterogeneity of observed effects (activation by IFN- $\gamma$, immune accessory function implicating responsiveness to various cytokines) suggests that in FS cell populations both class I and class II signaling pathways may become activated. Activation of one of the two pathways may depend on the physiological condition or, alternatively, distinct pathways may be used in different FS cell subpopulations $(80,99)$. 
A similar complexity is reflected in the expression of tissue-inhibitors of metalloproteinases (TIMPs) in pituitary cells: constitutive TIMP-II expression was observed in the FS cell line TtT/GF (83), whereas several of the cytokines produced by pituitary cells (IL-6, IL-10, LIF) - which are probably also produced within the FS cell compartment - were found to induce TIMP-I expression but not TIMP-II expression in various cell types including mononuclear phagocytes (100, 101). The expression of TIMPs has generally been related to the preservation of extracellular matrix (ECM) components in various tissues (101). On the other hand, pituitary FS cells were shown to be involved in degradation of the parenchymal basal lamina (89). Therefore, their role in regulating ECM integrity is probably a dual one, inclining towards ECM degradation in one physiological condition, and towards ECM preservation (through TIMPs) in other defined physiological conditions (89).

\section{New approaches for old questions}

One of the earliest ideas concerning the function of pituitary FS cells is that they represent a renewal or stem cell system in the anterior pituitary $(33,102)$. This idea regained interest in view of the revised definition of organ typic stem cells, advanced by the experimental findings of a neural stem cell system in the adult mammalian brain, an organ long considered to be entirely postmitotic (31). In the mammalian brain, pluripotent neural stem cells have been discovered that not only have a potentiality extending beyond the region of the brain from which they are derived, but also may not be restricted to the brain at all $(31,32)$. This innovative concept of a putative common neuro/hematopoietic stem cell in the adult mammalian forebrain (32), together with our own observations of a population of BM-related cells in the pituitary interstitial cell compartment $(6,67$, 68), prompts a revitalization of Yoshimura's concept of a pituitary cell renewal system $(33,102)$.

A number of papers have recently provided evidence, although only circumstantially, for a role of FS cells as adult stem cells in the anterior pituitary $(34,37)$. Horvath \& Kovacs (37) demonstrated that in a large series of adenomatous and non-tumorous human pituitaries, immunoreactivities to S-100 and GFAP were strongest in newly formed follicles, the older microcysts being immunonegative. According to Horvath \& Kovacs (37), these findings signified that endocrine cells retrodifferentiated into FS cells, suggesting that the latter represent a type of pluripotent adult stem cell.

Inoue and co-workers reported that skeletal muscle cells could differentiate from FS cells when a pituitary gland was transplanted under the kidney capsule (34). They confirmed this finding in vitro by showing the differentiation of Tpit/F1 cells into striated muscle cells (35). Tpit/F1 cells reveal characteristics of FS cells; however, they also express pituitary endocrine cell-specific transcription factor pit-1 and PRL genes (35).

Finally, we recently identified the expression of nestin, an intermediate filament protein originally described in neural stem cells and also found in putative stem/progenitor cells of other tissues, in a small number of S-100 ${ }^{+}$cells (103). In addition, a subpopulation of S-100 mRNA-expressing cells segregated into the socalled 'side population' (SP) of the anterior pituitary (H Vankelecom, unpublished observations). SP cells are characterized by efficient Hoechst dye-efflux capacity and visualized as a streak of cells using dual-wavelength flow cytometry. Cells with SP phenotype are identified in an increasing number of tissues, where they typically represent a population enriched in cells with stem/progenitor cell characteristics (104). Also the anterior pituitary SP displays stem cell characteristics (H Vankelecom, unpublished observations).

A stem cell function of FS cells and lineal relationships may be studied using novel transgenic technologies such as the Cre/loxP recombination system (79). In this system, transgenic expression of the P1 phage recombinase Cre under control of the promoter of an FS cell-specific product triggers permanent activation of a reporter gene which not only marks the FS cells, but remains detectable in cells derived from FS cells. The feasibility of this approach awaits the identification of an FS cell-specific product which is expressed in most if not all FS cells. Characterization of such a factor may occur in the course of the search of a universal evolutionary marker as mentioned above (see 'Immunophenotype and embyological origin'). Use of the S-100 promoter would only target a subset of FS cells, and may also mark pituitary cells derived from other (neural) S-100-expressing cells. An equally important caveat is about the reliability of the promoter used to target Cre: expression of Cre should be highly accurate, and only occur in the FS cell population. Leaky expression in some hormone-secreting cells, for instance, could be misinterpreted as a lineage relationship between FS cells and those hormonesecreting cells. This caution also applies to an alternative transgenic approach in which FS cells are destroyed using diphtheria toxin A, or the regulatable 'thymidinekinase obliteration' system. In this model, renewal of hormone-secreting cells would be compromised if FS cells represent the stem cell population.

As a complementary approach, FS cell fate and differentiation can also be studied in available transgenic mouse models in which pituitary development is affected. To date, the pituitary is a very much solicited 'developmental paradigm'. The output of transgenic models generated a comprehensive view on the development and differentiation of several pituitary cell lineages (for review see 105). In these models, however, only hormone-secreting cell types have been analyzed, while FS cells were ignored. Looking in detail at S-100 or other FS cell markers should reveal aspects 
of FS cell lineage development such as possible relationships to other pituitary or brain cells, and the role of specific growth and transcription factors in FS cell development.

Many questions remain with respect to the heterogeneity within the FS cell compartment. Are subpopulations involved which are of different origin, of different functional condition, or of different differentiation state imposed by the local environment? Immortalized FS cell lines could be useful tools to study these questions. Again, discovery of FS cell-specific products would allow creation of such cell lines by genetic approaches, as has been succesfully demonstrated for the gonadotrope/thyrotrope cell lineage and precursors (for review see 106).

\section{Acknowledgements}

Many university laboratories have been involved in the study of the pituitary FS cells during the last decade, and we especially call to mind the research groups of Carl Denef (University of Leuven, Belgium), Hemmo A Drexhage (Erasmus University Rotterdam, The Netherlands), Karl Bauer (Max-Planck-Institut Hannover, Germany), Patrice Mollard (INSERM Unité 469, Montpellier, France), Joseph Köhrle (University of Würzburg, Germany), Kinji Inoue (Saitama University, Japan) and others who have made important contributions to our understanding of this intriguing subject. K Bauer, P Mollard and Leendert Looijenga (Josephine Nefkens Institute, Rotterdam, The Netherlands) are acknowledged for suggestions and critically reading the manuscript.

\section{References}

1 Rinehart JF \& Farquhar MG. Electron microscopic studies of the anterior pituitary gland. Journal of Histochemistry and Cytochemistry $1953193-113$.

2 Farquhar MG. 'Corticotrophs' of the rat adenohypophysis as revealed by electron microscopy. Anatomical Record 1957127 291 (Abstract).

3 Vila-Porcile E. Le réseau des cellules folliculo-stellaires et les follicules de l'adénohypophysis du rat (pars distalis). Zeitschrift für Zellforschung und Mikroskopische Anatomie 1972129 328-369.

4 Allaerts W, Carmeliet P \& Denef C. New perspectives in the function of pituitary folliculo-stellate cells. Molecular and Cellular Endocrinology $1990 \mathbf{7 1} 73-81$.

5 Dyson M. Endocrine system. In Gray's Anatomy, edn. 38, pp 1882-1888. Ed. S Standring. Edinburgh, London, New York: Churchill Livingstone, 1995.

6 Allaerts W, Fluitsma DM, Hoefsmit ECM, Jeucken PHM, Morreau H, Bosman FT \& Drexhage HA. Immunohistochemical, morphological and ultrastructural resemblance between dendritic cells and folliculo-stellate cells in normal human and rat anterior pituitaries. Journal of Neuroendocrinology 19968 17-29.

7 Hoek A, Allaerts W, Leenen PJM, Schoemaker J \& Drexhage HA. Dendritic cells and macrophages in the pituitary and the gonads. Evidence for their role in the fine regulation of the reproductive endocrine response. European Journal of Endocrinology 1997136 $8-24$.
8 Herkenham M. Folliculo-stellate (FS) cells of the anterior pituitary mediate interactions between the endocrine and immune systems. Endocrinology $200514633-34$.

9 Ferrara N, Schweigerer L, Neufeld G, Mitchell R \& Gospodarowicz D. Pituitary follicular cells produce basic fibroblast growth factor. PNAS 198784 5773-5777.

10 Ferrara N \& Henzel WJ. Pituitary follicular cells secrete a novel heparin-binding growth factor specific for vascular endothelial cells. Biochemical and Biophysical Research Communications 1989 $161851-858$.

11 Gospodarowicz D \& Lau K. Pituitary follicular cells secrete both vascular endothelial growth factor and follistatin. Biochemical and Biophysical Research Communications $1989165292-298$.

12 Ferrara N, Winer J \& Henzel WJ. Pituitary follicular cells secrete an inhibitor of aortic endothelial cell growth: identification as leukemia inhibitory factor. PNAS 199289 698-702.

13 Vankelecom H, Carmeliet P, Van Damme J, Billiau A \& Denef C. Production of interleukin-6 by folliculo-stellate cells of the anterior pituitary gland in a histiotypic cell aggregate culture system. Neuroendocrinology $1989 \mathbf{4 9} 102-106$.

14 Tierney T, Patel R, Stead CA, Leng L, Bucala R \& Buckingham JC. Macrophage migration inhibitory factor is released from pituitary folliculo-stellate-like cells by endotoxin and dexamethasone and attenuates the steroid-induced inhibition of interleukin 6 release. Endocrinology 2005146 35-43.

15 Swennen L, Baes M \& Denef C. $\beta$-Adrenergic stimulation of cAMP in primary cultures of rat anterior pituitary cell populations separated by unit gravity sedimentation. Neuroendocrinology $1985 \mathbf{4 0} 78-83$.

16 Otto C, Dieck ST \& Bauer K. Dipeptide uptake by adenohypophysial folliculostellate cells. American Journal of Physiology 1996 271 C210-C217.

17 Vankelecom H, Andries M, Billiau A \& Denef C. Evidence that folliculo-stellate cells mediate the inhibitory effect of interferon- $\gamma$ on hormone secretion in rat anterior pituitary cell cultures. Endocrinology $19921303537-3546$.

18 Ceccatelli S, Hulting A-L, Zhang X, Gustafsson L, Villar M \& Hökfelt T. Nitric oxide synthase in the rat anterior pituitary gland and the role of nitric oxide in regulation of luteinizing hormone secretion. PNAS 199390 11292-11296.

19 Vankelecom H, Matthys P \& Denef C. Inducible nitric oxide synthase in the anterior pituitary gland: induction by interferon- $\gamma$ in a subpopulation of folliculostellate cells and in an unidentifiable population of non-hormone secreting cells. Journal of Histochemistry and Cytochemistry $1997 \mathbf{4 5} 847-857$.

20 Vankelecom H, Matthys P \& Denef C. Involvement of nitric oxide in the interferon- $\gamma$-induced inhibition of growth hormone and prolactin secretion in anterior pituitary cell cultures. Molecular and Cellular Endocrinology 1997129 157-167.

21 Kato M. Involvement of nitric oxide in growth hormone (GH)releasing hormone-induced $\mathrm{GH}$ secretion in rat pituitary cells. Endocrinology $19921312133-2138$.

22 Borst JGG, Lodder JC, Roubos EW \& Kits KS. In situ recordings of presumed folliculo-stellate cells in the intermediate lobe of the pituitary gland of Xenopus laevis. Neuroscience Letters 1996 $20961-64$.

23 Ferrara N, Fuji DK, Goldsmith PC, Widdicombe JH \& Weiner RI. Transport epithelial characteristics of cultured bovine pituitary follicular cells. American Journal of Physiology (Endocrinology and Metabolism 15) 1987252 E304-E312.

24 Baes M, Allaerts W \& Denef C. Evidence for functional communication between folliculo-stellate cells and hormone-secreting cells in perifused anterior pituitary cell aggregates. Endocrinology $1987 \mathbf{1 2 0} 685-691$.

25 Allaerts W \& Denef C. Regulatory activity and topological distribution of folliculo-stellate cells in rat anterior pituitary cell aggregates. Neuroendocrinology 198949 409-418.

26 Mira-Moser F, Schofield JG \& Orci L. Tight junction between follicular cells of the anterior pituitary gland: a freeze-fracture study. Journal de Microscopie et de Biologie Cellulaire 197522 117-120. 
27 Fletcher WH, Anderson NC \& Everett JW. Intercellular communication in the rat anterior pituitary gland. An in vivo and in vitro study. Journal of Cell Biology 197567 469-476.

28 Fauquier T, Guérineau NC, McKinney RA, Bauer K \& Mollard P. Folliculostellate cell network: a route for long-distance communication in the anterior pituitary. PNAS $2001 \mathbf{9 8}$ $8891-8896$.

29 Prummel MF, Brokken LJS, Meduri G, Misrahi M, Bakker O \& Wiersinga WM. Expression of the thyroid-stimulating hormone receptor in the folliculo-stellate cells of the human anterior pituitary. Journal of Clinical Endocrinology and Metabolism 200085 4347-4353.

30 Brokken LJ, Bakker O, Wiersinga WM \& Prummel MF. Functional thyrotropin receptor expression in the pituitary folliculo-stellate cell line TtT/GF. Experimental and Clinical Endocrinology and Diabetes $200511313-20$.

31 Gage FH. Mammalian neural stem cells. Science $2000 \mathbf{2 8 7}$ $1433-1438$.

32 Bjornson CRR, Rietze RL, Reynolds BA, Magli MC \& Vescovi AL. Turning brain into blood; a hematopoietic fate adopted by adult neural stem cells in vivo. Science 1999283 534-537.

33 Yoshimura F, Harumiya K, Ishikawa H \& Ohtsuka Y. Differentiation of isolated chromophobes into acidophils or basophils when transplanted in the hypophysiotrophic area of hypothalamus. Endocrinologia Japonica 196916 531-540.

34 Inoue K, Mogi C, Ogawa S, Tomida M \& Miyai S. Are folliculostellate cells in the anterior pituitary gland supportive cells or organ-specific stem cells? Archives of Physiology and Biochemistry $200211050-53$

35 Mogi C, Miyai S, Nishimura Y, Fukuro H, Yokoyama K, Takaki A \& Inoue K. Differentiation of skeletal muscle from pituitary folliculo-stellate cells and endocrine progenitor cells. Experimental Cell Research 2004292 288-294.

36 Inoue K, Matsumoto H, Koyama C, Shibata K, Nakazato Y \& Ito A. Establishment of a folliculo-stellate-like cell line from a murine thyrotropic pituitary tumor. Endocrinology 1992131 $3110-3116$

37 Horvath E \& Kovacs K. Folliculo-stellate cells of the human pituitary: a type of adult stem cell? Ultrastructural Pathology $2002 \mathbf{2 6}$ 219-228.

38 Kineman RD, Faught WJ \& Frawley LS. Steroids can modulate transdifferentiation of prolactin and growth hormone cells in bovine pituitary cultures. Endocrinology $19921303289-3294$.

39 Childs GV. Development of gonadotropes may involve cyclic transdifferentiation of growth hormone cells. Archives of Physiology and Biochemistry 2002110 42-49.

40 Taniguchi Y, Yasutaka S, Kominami R \& Shinohara H. Proliferation and differentiation of rat anterior pituitary cells. Anatomy and Embryology $2002 \mathbf{2 0 6} 1-11$.

41 Carbajo-Perez E \& Watanabe YG. Cellular proliferation in the anterior pituitary of the rat during the postnatal period. Cell and Tissue Research $1990261333-338$.

42 Nolan LA, Kavanagh E, Lightman SL \& Levy A. Anterior pituitary cell population control: basal cell turnover and the effects of adrenalectomy and dexamethasone treatment. Journal of Neuroendocrinology $1998 \mathbf{1 0} 207-215$.

43 Salazar H. The pars distalis of the female rabbit hypophysis: an electron microscopic study. Anatomical Record $1963 \mathbf{1 4 7}$ 469-497.

44 Kagayama M. The follicular cell in the pars distalis of the dog pituitary gland: an electron microscopic study. Endocrinology 196577 1053-1060.

45 Krisch B \& Buchheim W. Access and distribution of exogenous substances in the intercellular clefts of the rat adenohypophysis. Cell and Tissue Research 1984236 439-452.

46 Wilfinger WW, Larsen WJ, Downs TR \& Wilbur DL. An in vitro model for studies of intercellular communication in cultured rat anterior pituitary cells. Tissue and Cell 198416 483-497.

47 Allaerts W, Engelborghs Y, Van Oostveldt P \& Denef C. Evidence that folliculo-stellate cells do not impede the permeability of intercellular spaces to molecular diffusion in three-dimensional aggregate cell cultures of rat anterior pituitary. Endocrinology $19901271517-1525$.

48 Denef C \& Andries M. Evidence for paracrine interaction between gonadotrophs and lactotrophs in pituitary cell aggregates. Endocrinology $1983112813-822$.

49 Tilemans D, Andries M \& Denef C. Luteinizing hormone-releasing hormone and neuropeptide $\mathrm{Y}$ influence deoxyribonucleic acid replication in three anterior pituitary cell types. Evidence for mediation by growth factors released from gonadotrophs. Endocrinology $1991 \mathbf{1 3 0} 882-894$.

50 Nakajima T, Yamaguchi H \& Takahashi K. S100 protein in folliculo-stellate cells of the rat pituitary anterior lobe. Brain Research $1980191523-531$

51 Cocchia D \& Miani N. Immunocytochemical localization of the brain-specific S100 protein in the pituitary gland of adult rat. Journal of Neurocytology $19809771-782$.

52 Allaerts W, Tijssen AMI, Jeucken PHM, Drexhage HA \& de Koning J. Influence of folliculo-stellate cells on biphasic luteinizing hormone secretion response to gonadotropin-releasing hormone in rat pituitary cell aggregates. European Journal of Endocrinology 1994130 530-539.

53 Vankelecom H, Matthys P, Van Damme J, Heremans H, Billiau A \& Denef C. Immunocytochemical evidence that S-100-positive cells of the mouse anterior pituitary contain interleukin-6 immunoreactivity. Journal of Histochemistry and Cytochemistry $199341151-156$.

54 Ishikawa H, Nogami H \& Shirasawa N. Novel clonal strains from adult rat anterior pituitary producing S-100 protein. Nature $1983303711-713$

55 Baird A, Mormède P, Ying SH, Wehrenberg WB, Ueno N, Ling N \& Guillemin R. A nonmitogenic pituitary function of fibroblast growth factor: regulation of thyrotropin and prolactin secretion. PNAS $1985 \mathbf{8 2}$ 5545-5549.

56 Spangelo BL, Judd AM, Isakson PC \& MacLeod RM. Interleukin-6 stimulates anterior pituitary hormone release in vitro. Endocrinology 1989125 575-577.

57 Vankelecom H, Carmeliet P, Heremans H, van Damme J, Dijkmans R, Billiau A \& Denef C. Interferon- $\gamma$ inhibits stimulated adrenocorticotropin, prolactin and growth hormone secretion in normal rat anterior pituitary cell cultures. Endocrinology 1990 $1262919-2926$.

58 Allaerts W, Koopman WJH, Verlaan BPJ, Buzzi M \& Steerenberg PA. Endogenous production of nitric oxide and effects of nitric oxide and superoxide on melanotrope functioning in the pituitary pars intermedia of Xenopus laevis. Nitric Oxide: Biology and Chemistry 20004 15-28.

59 Tierney T, Christian HC, Morris JF, Solito E \& Buckingham JC. Evidence from studies on co-cultures of TtT/GF and AtT20 cells that Annexin 1 acts as a paracrine or juxtacrine mediator of the early inhibitory effects of glucocorticoids on ACTH release. Journal of Neuroendocrinology 200315 1134-1143.

60 Edwardson JA \& Gilbert D. Sensitivity of self-potentiating effect of luteinizing hormone-releasing hormone to cycloheximide. Nature 197525571

61 de Koning J, van Dieten JAMJ \& van Rees GP. LH-RH-dependent synthesis of protein necessary for LH release from rat pituitary glands in vitro. Molecular and Cellular Endocrinology $1976 \mathbf{5}$ 151-160.

62 Masumoto N, Tasaka K, Kasahara K, Miyake A \& Tanizawa O. Purification of gonadotropes and intracellular free calcium oscillation. Effects of gonadotropin-releasing hormone and interleukin 6. Journal of Biological Chemistry 1991266 6485-6488.

63 Tachibana O \& Yamashima T. Immunohistochemical study of folliculo-stellate cells in human pituitary adenomas. Acta Neuropathologica $1988 \mathbf{7 6} 458-464$.

64 Höfler H, Denk H \& Walter GF. Immunohistochemical demonstration of cytokeratins in endocrine cells of the human pituitary gland and in pituitary adenomas. Virchows Archives (Pathological Anatomy) $1984 \mathbf{4 0 4} 359-368$. 
65 Shirasawa N, Kihara H, Yamaguchi S \& Yoshimura F. Pituitary folliculo-stellate cells immunostained with S100 protein antiserum in postnatal, castrated and thyroidectomized rats. Cell and Tissue Research 1983231 235-249.

66 Kuwano R, Usui H, Maeda T, Fukui T, Yamanari N, Ohtsuka E, Ikehara M \& Takahashi Y. Molecular cloning and the complete nucleotide sequence of cDNA to mRNA for S-100 protein of rat brain. Nucleic Acids Research 198412 7455-7465.

67 Allaerts W, Salomon B, Leenen PJM, van Wijngaardt S, Jeucken PHM, Ruuls S, Klatzmann D \& Drexhage HA. A population of interstitial cells in the anterior pituitary with a hematopoietic origin and a rapid turnover: a relationship with folliculo-stellate cells? Journal of Neuroimmunology $1997 \mathbf{7 8}$ 184-197.

68 Allaerts W, Boonstra-Blom AG, Peeters K, Janse EM, Berghman LR \& Jeurissen SHM. Prenatal development of hematopoietic and hormone-producing cells in the chicken adenohypophysis. General and Comparative Endocrinology $1999114213-224$.

69 Zeid NA \& Muller HK. S100 positive dendritic cells in human lung tumors associated with cell differentiation and enhanced survival. Pathology 199325 338-343.

70 Salomon B, Lorès P, Pioche C, Racz P, Jami J \& Klatzmann D. Conditional ablation of dendritic cells in transgenic mice. Journal of Immunology 1994152 537-548.

71 Springer T, Galfré D, Secher S \& Milstein C. Mac-1: a macrophage differentiation antigen identified by monoclonal antibody. European Journal of Immunology 19799 301-306.

72 Fleming JC, Pahl HL, González DA, Smith TF \& Tenen DG. Structural analysis of the CD11b gene and phylogenetic analysis of the alpha-integrin gene family demonstrate remarkable conservation of genomic organization and suggest early diversification during evolution. Journal of Immunology 1993150 480-490.

73 Kraal G \& Janse M. Marginal metallophilic cells of the mouse spleen identified by a monoclonal antibody. Immunology 1986 58 665-669.

74 Mooij P, Simons PJ, de Haan-Meulman M, de Wit HJ \& Drexhage HA. Effect of thyroid hormones and other iodinated compounds on the transition of monocytes into veiled/dendritic cells: role of granulocyte-macrophage colony-stimulating factor, tumour-necrosis factor- $\alpha$ and interleukin-6. Journal of Endocrinology $1994140503-512$.

75 Jeurissen SHM, Janse EM, Koch G \& de Boer GF. The monoclonal antibody CVI-ChNl-68.1 recognizes cells of the monocytemacrophage lineage in chickens. Developmental and Comparative Immunology 198812 855-864.

76 Schmale MC, Gill KA, Cacal SM \& Baribeau SD. Characterization of Schwann cells from normal nerves and from neurofibromas in the bicolour damselfish. Journal of Neurocytology 199423 668-681.

77 Nakagawa F, Schulte BA \& Spicer SS. Glycoconjugate localization with lectin and PA-TCH-SP cytochemistry in rat hypophysis. American Journal of Anatomy $1985 \mathbf{1 7 4} 61-81$.

78 Acarin L, Vela JM, González B \& Castellano B. Demonstration of poly-N-acetyl lactosamine residues in ameboid and ramified microglial cells in rat brain by tomato lectin binding. Journal of Histochemistry and Cytochemistry $1994 \mathbf{4 2} 1033-1041$.

79 Akagi K, Sandig V, Vooijs M, Van der Valk M, Giovannini M, Strauss M \& Berns A. Cre-mediated somatic site-specific recombination in mice. Nucleic Acids Research 199725 1766-1773.

80 Allaerts W, Jeucken PHM, Debets R, Hoefakker S, Claassen E \& Drexhage HA. Heterogeneity of pituitary folliculo-stellate cells: implications for interleukin-6 production and accessory function in vitro. Journal of Neuroendocrinology 19979 43-53.

81 Spangelo BL, MacLeod RM \& Isakson PC. Production of interleukin-6 by anterior pituitary cells in vitro. Endocrinology 1990126 $582-586$.

82 Inoue K, Couch EF, Takano K \& Ogawa S. The structure and function of folliculo-stellate cells in the anterior pituitary gland. Archives of Histology and Cytology 199962 205-218.
83 Matsumoto H, Ishibashi Y, Ohtaki T, Hasegawa Y, Koyama C \& Inoue K. Newly established murine pituitary folliculo-stellatelike cell line (TtT/GF) secretes potent pituitary glandular cell survival factors, one of which corresponds to metalloproteinase inhibitor. Biochemical and Biophysical Research Communications $1993194909-915$.

84 Matsumoto H, Koyama C, Sawada T, Koike K, Hirota K, Miyake A, Arimura A \& Inoue K. Pituitary folliculo-stellatelike cell line (TtT/GF) responds to novel hypophysiotropic peptide (pituitary adenylate cyclase-activating peptide), showing increased adenosine $3^{\prime}, 5^{\prime}$-monophosphate and interleukin-6 secretion and proliferation. Endocrinology $1993 \quad 133$ 2150-2155.

85 Tatsuno I, Somogyvari-Vigh A, Mizuno K, Gottschall PE, Hidaka H \& Arimura A. Neuropeptide regulation of interleukin- 6 production from the pituitary: stimulation by pituitary adenylate cyclase activating polypeptide and calcitonin generelated peptide. Endocrinology 1991129 1797-1804.

86 Wong ML, Bongiorno PB, Rettori V, McCann SM \& Licinio J. Interleukin (IL) $1 \beta$, IL-1 receptor antagonist, IL-10, and IL-13 gene expression in the central nervous system and anterior pituitary during systemic inflammation: pathophysiological implications. PNAS $199694227-232$.

87 Ueta Y, Levy A, Chowdrey HS \& Lightman SL. S-100 antigenpositive folliculostellate cells are not the source of IL-6 gene expression in human pituitary adenomas. Journal of Neuroendocrinology $19957467-474$.

88 Höfler H, Walter GF \& Denk H. Immunohistochemistry of folliculo-stellate cells in normal human adenohypophysis and in pituitary adenomas. Acta Neuropathologica 198465 35-40.

89 Schechter J, Ahmad N \& Weiner R. Activation of anterior pituitary folliculo-stellate cells in the formation of estrogen-induced prolactin-secreting tumors. Neuroendocrinology $1988 \quad \mathbf{4 8}$ 569-576.

90 Velkeniers B, Vergani P, Trouillas J, D’Haens J, Hooghe RJ \& Hooghe-Peeters EL. Expression of Il- 6 mRNA in normal rat and human pituitaries and in human pituitary adenomas. Journal of Histochemistry and Cytochemistry 199442 67-76.

91 Jones TH, Daniels M, James RA, Justice SK, McCorkle R \& Price A. Production of bioactive and immunoreactive IL- 6 and expression of IL-6 mRNA by human pituitary adenomas. Journal of Clinical Endocrinology and Metabolism 199478 180-187.

92 Aloisi F, Rosa S, Testa U, Bonsi P, Russo G, Peschle C \& Levi G. Regulation of leukemia inhibitory factor synthesis in cultured human astrocytes. Journal of Immunology $1994 \mathbf{1 5 2}$ 5022-5031.

93 Castro CP, Nagashima AC, Pereda MP, Goldberg V, Chervin A, Largen P, Renner U, Stalla GK \& Arzt E. The gp130 cytokines interleukin-11 and ciliary neurotropic factor regulate through specific receptors the function and growth of lactosomatotropic and folliculostellate pituitary cell lines. Endocrinology 2000 141 1746-1753.

94 Kobayashi H, Fukuta J, Murakami N, Usui T, Ebisui O, Muro S, Hanaoka I, Inoue K, Imura H \& Nakao K. Tumor necrosis factor receptors in the pituitary cells. Brain Research $1997 \mathbf{7 5 8}$ 45-50.

95 Brokken LJ, Leendertse M, Bakker O, Wiersinga WM \& Prummel MF. Expression of adenohypophyseal-hormone receptors in a murine folliculo-stellate cell line. Hormone and Metabolic Research 200436 538-541.

96 Melmed S. A redundant cytokine network in the neuro-immunoendocrine regulation of the HPA axis. Journal of Clinical Investigation $1995951288-1298$.

97 Benigni F, Fantuzzi G, Sacco S, Sironi M, Pozzi P, Dinarello CA, Sipe JD, Poli V, Cappelletti M, Paonessa G, Pennica D, Panayotatos N \& Ghezzi P. Six different cytokines that share GP130 as a receptor subunit, induce serum amyloid A and potentiate the induction of interleukin- 6 and the activation of the hypothalamus-pituitary-adrenal axis by interleukin-1. Blood $1996871851-1854$. 
98 Taga T \& Kishimoto T. Signal transduction through class I cytokine receptors. In Signal transduction, ch. 2, pp 19-36. Eds C-H Heldin \& M Purton. London: Chapman, Hall, 1996.

99 Cardin J, Carbajal ME \& Vitale ML. Biochemical and morphological diversity among stellate cells of the mink (Mustela vison) anterior pituitary. General and Comparative Endocrinology 2000 $12075-87$.

100 Lacraz S, Nicod LP, Chicheportiche R, Welgus HG \& Dayer JM. IL-10 inhibits metalloproteinase and stimulates TIMP-1 production in human mononuclear phagocytes. Journal of Clinical Investigation $1995962304-2310$.

101 Nemoto O, Yamada H, Mukaida M \& Shimmei M. Stimulation of TIMP-1 production by oncostatin $\mathrm{M}$ in human articular cartilage. Arthritis and Rheumatology 199639 560-566.

102 Yoshimura F, Soji T, Sato S \& Yokoyama M. Development and differentiation of rat pituitary follicular cells under normal and some experimental conditions with special reference to an interpretation of renewal cell system. Endocrinologia Japonica 197724 435-449.

103 Krylyshkina O, Chen J, Mebis L, Denef C \& Vankelecom H. Nestin-immunoreactive cells in rat pituitary are neither hormonal nor typical folliculo-stellate cells. Endocrinology $2005 \mathbf{1 4 6}$ $2376-2387$.

104 Goodell MA, Brose K, Paradis G, Conner AS \& Mulligan RC. Isolation and functional properties of murine hematopoietic stem cells that are replicating in vivo. Journal of Experimental Medicine $19961831797-1806$.

105 Dasen JS \& Rosenfeld MG. Combinatorial codes in signaling and synergy: lessons from pituitary development. Current Opinion in Genetics and Development $19999566-574$.

106 Mellon PL, Windle JJ \& Weiner RI. Immortalization of neuroendocrine cells by targeted oncogenesis. Recent Progress in Hormone Research 199147 69-93.

107 Wolswijk G \& Noble M. Identification of an adult-specific glial progenitor cell. Development 1989105 387-400.

108 Kurotani R, Tahara S, Sanno N, Teramoto A, Mello PL, Inove K, Yoshimura S \& Osamura RY. Expression of Ptx1 in the adult rat pituitary glands and pituitary cell lines: hormone-secreting cells and folliculo-stellate cells. Cell and Tissue Research 1999298 55-61.

109 Koike K, Zhang ZX, Sakamoto Y, Kanda Y, Murakami K, Miyake A \& Inoue M. The pituitary folliculo-stellate cell line TtT/GF augments basal and TRH-induced prolactin secretion by GH3 cell. Life Sciences $1997612491-2497$.

Received 28 February 2005

Accepted 13 April 2005 